\title{
Safety Precautions Against the Coronavirus Pandemic to be Adopted in the Working Environment
}

\author{
Dr. A. Yudhistra Kumar* and Linga Murthy \\ "Head of the Department Environment, \\ Health and Safety
}

\begin{abstract}
EMERGING OF COVID-19
In the latest pandemic that is affecting human health and economy across the world. COVID-19 pandemic have been erupted from the Wuhan City of People's Republic (PR) of China in December 2019. The PR of China, under its obligations for International Health Regulations (2005), reported to the World Health Organization (WHO) that between December 31, 2019 and January 3, 2020, 44 cases with pneumonia of unknown aetiology had taken place, the disease Spread rapidly within and outside the Hubei Province, which has resulted in the spreading across large number of countries such as Thailand, Japan and the Republic of Korea [1] as they are initially affected countries, later which had spread to many countries in the world, which has resulted in the lock down in their countries because of the emerging pandemic. The Chinese authorities identified the virus to be a new coronavirus which was subsequently named as severe acute respiratory syndrome (SARS)-CoV-2 by the International Committee on Taxonomy of Viruses [2]. The WHO also named the disease due to this virus as COVID-19 [3]

The Pandemics of various infectious diseases with millions dying have been recorded in the history for past several centuries. It is obvious that the most well known in the history have been pandemic due to plague [4] from the Asian countries and the pandemic which has killed millions of people in the past [5]. In the current millennium too, and COVID-19 is the latest and are certainly not the last pandemic. One of the reasons for the occurrence and delayed response to pandemics is the lacklustre approach to building capacity to respond to the infectious diseases. With the availability of antibiotics, even the Surgeon General of the United States of America, William Stewart, said in 1967, "The time has come to close the book on infectious diseases" [6] But it was not to be. The past three decades have seen emergence of almost 40 new pathogens, most of which are viruses including HIV, hepatitis $\mathrm{C}$ virus and coronaviruses that have caused pandemics, novelinfluenza viruses etc [7]. Many non-technical but popular publications have also highlighted the Persistence and revival of infectious diseases. In the existing world there are many non-technical publications, which are made in the past has given more scientific information about the existence and revival of the infections, which causes diseases [8].
\end{abstract}

The Government of India and the state government have taken a decision to run the essential service industries, which are producing the essential goods such as Food industry and Active pharmaceutical (API) ingredient and their formulations units. One of the famous multinational companies (MNC), which is producing drugs like Azithromycin Dihydrate and Azithromycin monohydrate, which are needed to fight global menace against the COVID-19. These drugs are treated as front line treating of the infected persons of COVID-19. It is very much essential to run the API and formulation units to full fill the demands of the needed medicines to be given to the patients who are affected due to the various infections Specially COVID-19. In the present scenario on the $26^{\text {th }}$ March 2020 one of the employees who were working in the API unit of that MNC returned from Mandya [9] found infected by pandemics. He has travelled from Mysuru, from Mandya Bus Stand, in the Karnataka state transport buses. From Mysuru, he used to commute in his company shuttle. His primary contacts, his family members, parents, younger sister, and his niece have been subject to home quarantine," and also the MNC API unit has been shut down. So considering the essentially needed drugs, the employees of the API and other essential commodity units along with other units, which will be opened after the lock down, should follow basic safety precautions in order to prevent the community spread of the COVID -19 .

\section{SAFETY PRECAUTIONS AND PROTECTION MEASURES AGAINST THE PANDEMIC}

Individual protection measures by the employees should be an integral part of infection control in the factory premises, which reflects a level of personal commitment and action to be taken beyond the factory and governmental policies towards containment and mitigation of the disease, which plays a vital role when strict rules and safety regulations to be followed inside and outside the working environment. The evidence from earlier outbreaks advocate that face and hand hygiene reduce respiratory illnesses in the working environment and in turn allay the impact of pandemics [10]. All the employees should practise frequent hand washing with soap and water may significantly reduce the chance of acquiring and transmitting the infection among the employees, which should be made as an essential practise in the working environment. Individual employees are to be encouraged to practice respiratory hygiene and 
they should be trained by the safety department about the benefits of the use of the respiratory mask. In case a person working in the factory develops respiratory symptoms, in that scenario a medical attention is recommended immediately. However, wearing personal protective equipment (PPE) like rubber gloves in the factory is recommended in the chemical factory, although it is needed for the safe handling of the chemicals in the API industry. Safe chemical handling practice and procedures should be followed during the handling of the chemicals for the process in the Chemical industry. It is very much necessary to read the warning on the labels of the chemical used in the API industry and also should refer the Master Safety Data sheet (MSDS) before using the chemical for the process in the API industry. In this regard all the employee should be trained to handle the chemicals. Do not store together or mix incompatible chemicals together such as HCL/sulphuric acid with sodium hydroxide. Always it is necessary to do a compatible study before handling the chemicals. For example a person is handling sodium hydroxide/sulphuric acid in an chemical industry, then in that scenario he should use suitable kind of gloves (Nitrile Gloves), which is recommended by European union such as EN AJKL with Accepted quality Level (AQL) - 3 nitrile gloves, where $\mathrm{K}$ and $\mathrm{L}$ of nitrile gloves stands for resistance to sodium hydroxide $40 \%$ and sulphuric acid of $96 \%$ concentration and AQL level -3 , which refers to the pin hole defects of $0.5 \%$ defects from the random sampling. In the present pandemic scenario every employees are recommended before and after using the nitrile gloves appropriate hand hygiene to be maintained. In the industry Disinfection and cleansing of frequent touched surfaces should be carried out on daily basis [11, 12, 13]. The employee who is working in the working environment should see that he is maintaining the community distancing of one meter to be adopted among the people to restrict and protect

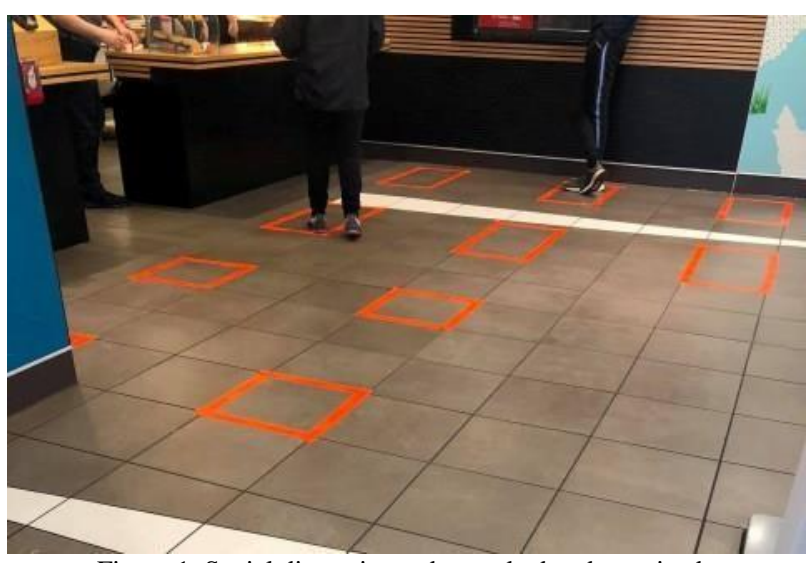

Figure.1. Social distancing to be marked and practiced

against the prevailing pandemic (Figure.1). In the entrance of the factory near to security room, prevention of spread of coronavirus (Covid-19) to be displayed (Figure.2) and proper training to be given to employees in this regard.

\section{PREVENT THE SPREAD OF CORONA VIRUS (COVID-19)}
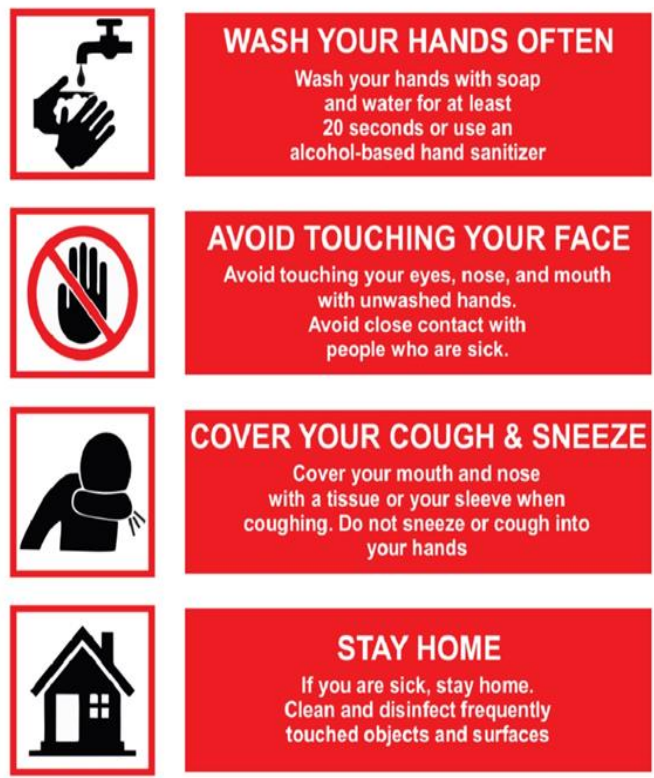

Figure.2. Prevent the spread of Corona virus board to be displayed at the entrance of the factory, neat to the security room

\section{Home isolation to be adopted by employees during the risky circumstances}

Thermal screaming of the temperature to be performed in front of the entrance gate of the factory when an employee enters in to the factory for working (Figure.2) and it should be recorded monitored on daily basis. In case an employee is suspected of an increased

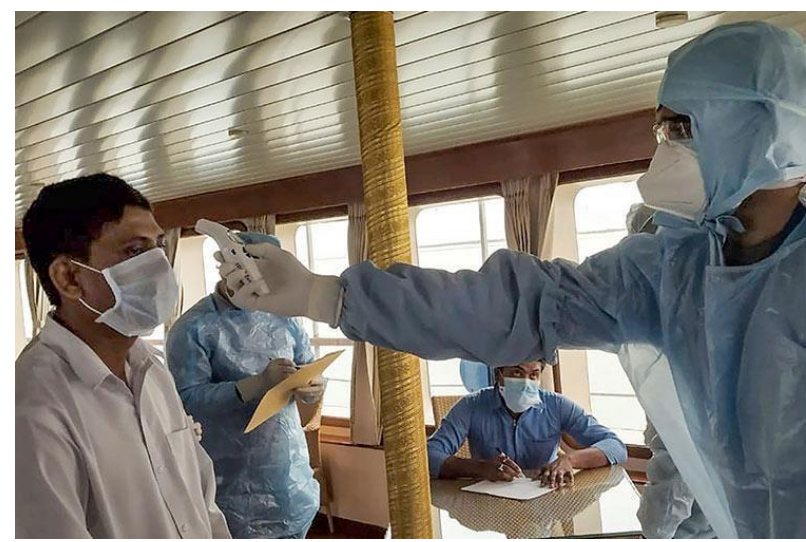

Figure.2. Thermal Temperature Screening of the employees to be performed

temperature, which has resulted in the sickness, in that scenario home isolation to be adopted with the suspected COVID-19 patient. The first healthcare contact can be managed at home if presenting with a mild illness, and there is no concern of rapid deterioration of an employee. The employee who is at home can be managed symptomatically with oral paracetamol. The suspected employee patient need to be placed in a well-ventilated single room at home, with their movements is limited 
within the house and their shared space should be minimized. A single care giver should optimally be chosen from among the household members and visitors should not be permitted until the suspected COVID-19 person at the home is completely recovered. Respiratory masks are to be worn by both the suspected employee at the house and the care giver and their dedicated cloths for wearing and eating utensils should be assigned separately for the employee patient at home. All individuals in close contact with the patient with suspected of COVID-19 should be considered for quarantine and their health should be monitored for 14 days from the last day of interaction [14]. A fitness certificate from the doctor is recommended before joining the duty by the employee that he is free from any pandemic such as COVID-19, so that spreading among the employees can be restricted.

\section{ABOUT THE TREATMENT AND TESTING FACILITY} Initially, testing facilities for COVID-19 by reverse transcription-polymerase chain reaction (RT-PCR) laid with government facilities alone, with the Indian Council of Medical Research (ICMR) recommending that the testing of only those symptomatic employees or the patients with a history of international travel from the affected countries or a history of close contact with a laboratory- confirmed positive case [15]. In case of industry the people who have travelled from abroad for business and trade purpose they should be tested without fail before he comes to the factory for joining the duty and recommended to bring a medical fitness certificate from the Government Hospital. Now that India has scaled up the diagnostic and laboratory testing for COVID-19 virus considering the dire urgency for enhanced number of cases for the detection to curb the dissemination of the disease. There is a need to secure adequate clinical infrastructure in the country with ample supply of personal protective equipment for the healthcare professionals who are treating the COVID-19 infected people. The ICMR- National Institute of Virology, Pune, has succeeded in retrieving the COVID-19 strain from infected patients, confirming a homology of 99.98 per cent with the strain from Wuhan [16]. This could imply that similar patterns of disease transmission can be expected if robust strategies to tackle the infection are not in place in the working environment. It also gives hope to the possible development of newer diagnostics, therapeutics and vaccines to combat COVID19. A comprehensive approach is needed to break the chains of transmission, and more aggressive testing, early diagnosis and isolation along with adequate treatment seem to be the way forward in tackling this infection in the future.

\section{REFERENCES}

[1] World Health Organisation. Novel Coronavirus (2019-nCoV) situation Report-1. WHO. 2020 Available from https: www.who.int/docs/default-source/coronaviruse/situationreports/20200121-sitrep-1-2019-ncov.pdf?sfvrsn=20a99c10_4, accessed on February 262020

[2] Gorbalenya AE, Baker SC, Barric RS, de Groot RJ, Drosten C, Gulyaeva AA, et al. Severe acute respiratory syndrome-related to Coronavirus. The species and its viruses - a statement of the Coronavirus study group. bioRxiv 2020. Doi:https://doi.org/10.1101/2020.02.07.937862

[3] World Health Organization. Naming the Coronavirus disease (COVID-19) and the virus that causes it. Geneva. WHO: 2020

[4] Howard J. Plague explained. Science, 20 August, 2019. Available from https://www.nationalgeographic.com/science/health-andhuman-body/humnan-diseases/the-plague/, accessed on February 26, 2020

[5] Centers for Disease Control and prevention. Pandemics influenza. Pst pandemics. Atlanta; CDC: 2018, Available from https://cdc.gov/flu/pandemic-resources/basics/pastpandemics.html, accessed on February 23, 2020

[6] Ross U. Ethics and infectious diseases. Bull world health Organ 2008, 86: 654

[7] Bhatia R. Narain JP, plianbangchang S. Emerging infectious diseases in East and south east and south East Asia, In details R. Sullivan SG, Tan CC, editors. Public health in South east Asia. Berkely, USA: University of California press; 2012, p.43-78

[8] Dubois R. Mirage of health: Utopias, progress and biological change. New York: Muriwai Book; 2006

[9] R Saitsh Kumar, DHNS, Apr 09 2020, https://www.deccanherald.com/state/top-karnataka-stories/covid19-first-jubilant-related-victim-detected-in-mandya-823271.html

[10] Aiello AE, Murray GF, Perez V, Coulborn RM, Davis BM, Uddin M, et al. Mask use, hand hygiene, and seasonal influenzalike illness among young adults: A randomized intervention trial. J Infect Dis 2010; 201: 491-8

[11] World Health Organization. Coronavirus disease (COVID-19) Advice for the public. WHO;2020. Available from: https://www.who.int/emergencies/diseases/novel-coronavirus2019/advice-for-public accessed on March 17, 2020

[12] World Health Organization. Rational use of personal protective equipment for coronavirus disease 2019 (COVID-19): Interim guidance, 27 February 2020. WHO; 2020. Available from: https://apps.who.int/iris/bitstream/handle/10665/331215/WHO2019-nCov-IPCPPE_use-2020.1-eng.pdf, accessed from February 2020.

[13] Centers for Disease Control and Prevention. Coronavirus disease 2019 (COVID-19): How to protect yourself. Available from: https://www.cdc.gov/coronavirus/2019ncov/prepare/prevention.html, accessed on March 17, 2020

[14] World Health Organization. Home care for patients with COVID19 presenting with mild symptoms and management of their contacts: Interim guidance, 17 March 2020. WHO; 2020. Available from: https://www.who.int/publications-detail/homecare-for-patients-with-suspected-novel-coronavirus-(ncov)infection-presenting-with-mild-symptoms-and-management-ofcontacts, accessed on March 17, 2020

[15] Indian Council of Medical Research. Note on COVID-19 laboratory preparedness in India. New Delhi: ICMR; 2020. Available from: https://www.icmr.nic.in/sites/default/files/press_realease_files/IC MR_PressRelease_COVID_19.pdf, accessed on March 6, 2020

[16] Yadav PD, Potdar VA, Choudhary ML, Nyayanit DA, Agrawal M, Jadhav SM, et al. Full-genome sequences of the first two SARS-CoV-2 viruses from India. Indian J Med Res 2020; 151. doi: 10.4103/ijmr.IJMR_663_20. 